Passagens. Revista Internacional de História Política e Cultura Jurídica,

Rio de Janeiro: vol. 3 no.1, janeiro-abril 2011, p. 33-61.

\title{
A CONTEMPORANEIDADE DA PRISÃO E DO SISTEMA PUNITIVO: SISTEMA PÓS- CORRECIONAL NO CAPITALISMO DE BARBÁRIE ${ }^{1}$
}

\author{
PRISION AND PUNITIVE SYSTEM'S CONTEMPORANIETY: POST CORRECTIONAL \\ SYSTEM IN CAPITALISM OF BARBARIE
}

\section{LA CONTEMPORANEIDAD DE LA PRISIÓN Y DEL SISTEMA PUNITIVO: EL SISTEMA POST-CORRECCIONAL EN EL CAPITALISMO DE BARBARIE}

\section{LA PRISON ET LE SYSTÈME PUNITIF CONTEMPORAINS: SYSTÈME POST- CORRECTIONNEL DANS LE CAPITALISME DE BARBARIE}

\section{DOI: $\underline{10.5533 / 1984-2503-20113102}$}

Isac Tolentino de Araújo Júnior

\section{RESUMO}

O texto, a partir do referencial teórico da criminologia crítica, trabalha as profundas transformações do sistema penal, diante da nova configuração institucional capitalista, sobretudo pelo relacionamento entre sistema punitivo e estrutura social. Revolução tecnocientífica, transformações no mercado de trabalho, nova visão da atividade estatal e ampliação da liberdade das forças de mercado resultam em maior conflitualidade social e no aumento da população carcerária e das pessoas em conflito com a lei em todo o mundo ocidental. O Brasil, seguindo a tendência mundial, adota um novo modelo a partir da década de 90 , com profundas modificações na sistemática da política criminal. O texto trabalha, como exemplo, a Lei 10.792/2003, expressão da mudança na execução penal, e os debates envolvendo deputados e senadores durante a tramitação do projeto de lei no Congresso Nacional. A Lei 10.792/2003 cria o Regime Disciplinar Diferenciado, com a inabilitação ou completo isolamento do condenado, em uma ruptura com a função original da prisão, sobretudo de disciplinamento para o mercado de trabalho.

\footnotetext{
${ }^{1}$ O presente texto é parte da dissertação de mestrado defendida no Programa de Pós-Graduação em Sociologia e Direito da Universidade Federal Fluminense, orientada pela Professora Doutora Gizlene Neder e pela Professora Doutora Vera Malaguti Batista.
} 
Palavras-chave: sistema penal, estrutura social, criminologia crítica, regime disciplinar diferenciado.

\section{RESUMEN}

El texto, desde el marco teórico de la criminología crítica, estudia las profundas transformaciones del sistema penal ante la nueva estructura institucional capitalista, sobre todo la relación entre el sistema punitivo y la estructura social. Revolución tecno-científica, cambios en el mercado de trabajo, la nueva visión de la actividad estatal y la expansión de las fuerzas del mercado libre resultan en más conflicto social y aumento de la población carcelaria y de los que tienen conflictos con la ley en todo el mundo occidental. Brasil, siguiendo la tendencia mundial, adopta un nuevo modelo a partir de la década de 1990, con cambios profundos en la política criminal sistemática. El texto trabaja, como ejemplo, la Ley 10.792/2003, expresión del cambio en la ejecución penal, y los debates envolviendo a diputados y senadores durante la tramitación del proyecto de ley en el Congreso Nacional. La Ley 10.792/2003 crea el Régimen Disciplinario Diferenciado, con la inhabilitación o completo aislamiento del condenado, en una ruptura con la función original de la prisión, sobre todo de disciplina para el mercado de trabajo.

Palabras-clave: la transformación del sistema penal, la estructura social, la criminología crítica, Régimen Disciplinario Diferenciado.

\section{ABSTRACT}

The text, from the theoretical framework of critical criminology theory, works the deep transformations of the penal system, in front of the new institutional set-capitalist, especially the relationship between the punitive system and social structure. Technoscientific revolution, changes in the labor market, new view of state activity and expansion of free market forces result in greater social conflict and increasing prison population and increasing people in conflict with the law throughout the Western world. Brazil, following the world tendency, adopts a new model from the 90s, with profound changes in criminal police systematic. The text works, for example, the Act 10.792/2003, expression of change in criminal enforcement, and discussions involving representatives and senators during the course of the bill in Congress. The Act 10.792/2003 creates the Differentiated Disciplinary Regime, imposing disqualification or complete isolation of the convict, in a break with the original function of the prison, especially for the disciplining of the labor market.

Key-words: penal system transformations, social structure, critical criminology theory, Differentiated Disciplinary Regime. 


\section{RÉSUMÉ}

Le texte, à partir du référentiel théorique de la criminologie critique, aborde les profondes transformations du système pénal, face à la nouvelle configuration institutionnelle capitaliste, surtout au travers des relations entre système punitif et structure sociale. La révolution technoscientifique, les transformations du marché du travail, la nouvelle vision de l'activité étatique et la libéralisation des forces du marché ont pour conséquence une conflictualité sociale plus forte et l'augmentation de la population carcérale et des personnes en conflit avec la loi dans tout le monde occidental. Le Brésil, suivant la tendance mondiale, adopte un nouveau modèle à partir des années 1990, avec de profondes modifications dans la philosophie de la politique criminelle. Le texte analyse, comme exemple, la loi numéro 10.792/2003, expression du changement dans l'exécution pénale, ainsi que les débats impliquant députés et sénateurs lors de l'examen du projet de loi au Congrès National. La loi numéro 10.792/2003 crée le Régime Disciplinaire Différencié, imposant la « disqualification », ou isolement complet du condamné, ce qui constitue une rupture avec la fonction originelle de la prison, surtout dans le but de le discipliner en fonction des exigences du marché du travail.

Mots-clés: transformations du système pénal, structure sociale, criminologie critique, Régime Disciplinaire Différencié.

\section{INTRODUÇÃO}

O presente trabalho desenvolve uma pesquisa empírica e interdisciplinar, agregando o estudo da sociologia, do direito e da criminologia, através de pesquisa bibliográfica e documental. A pesquisa documental é referente aos debates no Congresso Nacional que deram origem à Lei 10.792/03, que criou o Regime Disciplinar Diferenciado (RDD), e seu discurso indutor e justificador. Esta lei está inserida numa conjuntura de profundas mudanças por que passa a política criminal no Brasil a partir da década de 1990 e expressa uma nova visão da execução penal fundada na incomunicabilidade do preso como solução para os problemas de insegurança que atingem a sociedade brasileira.

$\mathrm{Na}$ contemporaneidade capitalista, há um excesso de homens como resultado da revolução tecnocientífica após a Segunda Guerra Mundial. Diante do encolhimento estatal e da irrestrita liberdade das forças de mercado e do aumento dos conflitos sociais, a população carcerária é ampliada em todo o mundo ocidental, a chamada política de 
"tolerância zero". Nesse contexto, é que o direito penal passa por profundas transformações com a elaboração legislativa de normas que expressem o novo momento histórico.

Assim, estudamos a Lei 10.792/03, que instituiu o RDD no Brasil, e os debates parlamentares durante sua tramitação no Congresso Nacional. Essa análise desvenda 0 papel da mídia como uma agência executiva criminal e as prisões modernas como fábrica de imobilidade, isolamento e incomunicabilidade.

\section{A NOVA CONFIGURAÇÃO INSTITUCIONAL E O CÁRCERE}

A sociedade capitalista inaugurou um novo tipo de relacionamento entre ciência, tecnologia e indústria que foi responsável pelo incremento das potencialidades produtivas, sobretudo após a Revolução Industrial, numa extensão desconhecida e inimaginável para qualquer modo de produção anterior. Esse processo foi intensificado no período após a Segunda Grande Guerra, na chamada sociedade tecnológica, quando a ciência e a tecnologia passaram a determinar praticamente todas as formas de pensamento e os aspectos da vida cotidiana. A modernidade capitalista desenvolveu as forças de produção em um nível extraordinário e nunca antes visto na história humana, com o aumento significativo das coisas que podem ser produzidas e compradas e a maior acumulação de riqueza que a história conheceu.

O avanço do conhecimento científico e a conseqüente extensão quantitativa do processo produtivo, como resultado da aplicação prática do desenvolvimento tecnológico, eram apresentados como capazes de superar os problemas e contradições da ordem social, sobretudo as carências materiais a que são submetidos amplos agrupamentos sociais excluídos e marginalizados ${ }^{2}$. Mas a terceira revolução tecnocientífica, desenvolvida, sobretudo, após 1945, criou, na prática, um massivo desemprego pela substituição da mão de obra humana por procedimentos de automação da produção e resultou em graves consequências para os que vivem do trabalho. ${ }^{3}$ Gisálio Cerqueira e

\footnotetext{
${ }^{2}$ Mészáros, István (2004). O poder da ideologia, São Paulo: Boitempo.

${ }^{3}$ Lembramos de interessante passagem de Marx sobre as contradições da sociedade capitalista: "Nos dias de hoje, tudo parece grávido de seu contrário. As máquinas, dotadas do maravilhoso poder de abreviar e tornar mais fecundo o trabalho humano, em vez disso o levam à inanição e ao excesso. As fontes de riqueza que aparecem como novidade, por algum estranho e fatídico encantamento, são transformadas em fonte de privação. Os triunfos da arte parecem ser comprados com a perda do caráter. No mesmo ritmo em que a humanidade domina a natureza, o homem parece tornar-se escravo de outros homens ou de sua própria infâmia. Mesmo a luz pura da ciência parece incapaz de brilhar a não ser contra o pano de fundo escuro da ignorância. Todas as nossas invenções e nossos progressos parecem dotar as forças materiais de vida intelectual e embrutecer a vida humana, tornando-a uma força material. Este antagonismo entre, de um lado, a indústria e a ciência modernas, de outro, a miséria e a dissolução." Apud Eagleton, Terry (1999). Marx e a liberdade, São Paulo: Editora Unesp, p. 43.
} 
Gizlene Neder assinalam a "brutal expansão das forças produtivas propiciada pela microeletrônica, pela informática e pela robótica que aponta para a prevalência do trabalho improdutivo, da miniaturização e da redução do tempo de trabalho no universo da produção de bens e serviços." ${ }^{4}$

O mesmo trabalho pode ser realizado com os mesmos resultados econômicos por uma força de trabalho significativamente inferior e, consequentemente, com custos reduzidos. No capitalismo contemporâneo, desaparece a noção de anormalidade no desemprego; ao contrário, este passa a ser um fenômeno permanente e regular com a formação de um contingente humano que não será absorvido no mercado. Um grupo expressivo da população mundial não mais participa e nem participará da atividade laboral. Esse "excedente de pessoas sem lugar no capitalismo que se move a velocidade do sinal eletrônico tornou-se um dos principais problemas da contemporaneidade,5.

A partir da década de 70 , a mutação do trabalho assalariado e a consequente perda de poder dos que vivem do trabalho ${ }^{6}$ na relação entre as classes e na luta pelo controle do Estado resultou numa profunda transformação nas atividades estatais. A própria autonomia relativa conquistada pelas burocracias estatais em relação às forças sociais e econômicas hegemônicas, após séculos de conflitos e lutas, foi minada. A nível mundial, foi difundido o modelo político-econômico conhecido como neoliberalismo, que é o conjunto de medidas que se opõem ao Estado de Bem-Estar de estilo keynesiano e social-democrata e que leva ao afastamento do Estado da regulação da economia, permitindo que o mercado, com sua racionalidade própria, opere a desregulamentação. $O$ neoliberalismo contempla a abolição dos investimentos estatais na produção, eliminação do controle social sobre o fluxo financeiro, programa de privatização e desregulamentação dos níveis de tributação sobre os lucros.

Para Bourdieu, ganhou prestígio nesse período a ideia do fim do EstadoProvidência e da recomposição do capitalismo com um novo projeto hegemônico, cristalizado na ideologia neoliberal e nas novas condições de acumulação, que possui como diretriz a reforma estrutural da economia, fundada na noção de eficiência e no discurso da estabilidade, com a entrega da regularização do mundo econômico à sua

\footnotetext{
${ }^{4}$ Cerqueira Filho, Gisálio; Neder, Gizlene (1997). Emoção e Política, Porto Alegre: Sergio Antonio Fabris Editor, p. 12

${ }^{5}$ Friedman, Luis Carlos (2007). "O destino dos descartáveis na sociedade contemporânea". In: Melo, Marcelo Pereira de (org.) (2007). Sociologia e Direito: explorando as Interseções. Niterói: PSGDS Programa de Pós-graduação em Sociologia e Direito - Universidade Federal Fluminense, p. 149.

${ }^{6}$ A expressão "os que vivem do trabalho" é utilizada por Mészáros para designar os sujeitos emancipatórios da contemporaneidade capitalista. Mészáros, I. (2004). Op. cit.
} 
própria lógica - a lei do mercado, o capitalismo radical, sem freios ou limites ${ }^{7}$. Uma das principais características desse modelo é o corte entre o econômico e o social, no qual o que importa é o primeiro e a produtividade e a competitividade são convertidas nos objetivos fundamentais da ação humana.

A redução dos controles jurídicos e o desenvolvimento de instrumentos de comunicação permitiram criar um mercado financeiro unificado dominado pelos países ricos, que ocupam uma posição central na definição das regras do capitalismo contemporâneo, com a consequente perda de autonomia dos mercados financeiros nacionais. Os poderes nacionais são submetidos a constantes ameaças de ataques especulativos por parte de grandes fundos, que exercem uma coação estrutural sobre os países, dando a esse mecanismo uma aparência de irresistível. Não sem razão o neoliberalismo é apresentado como inevitável e desprovido de alternativas, o "fim das ideologias" ou o "fim da história".

Menegat afirma que as tendências contemporâneas do capitalismo aprofundam os principais e ameaçadores traços civilizatórios do capital: (1) concentração da riqueza em alguns países e famílias; (2) formação de um exército industrial de reserva (decorrente das crises cíclicas e da permanente revolução tecnológica); (3) queda da taxa de lucros contida com políticas contracionistas que representam a destruição parcial dos meios de produção e das forças produtivas; (4) e pauperização, em termos absolutos, das classes subalternas, o que representa a degradação social e insegurança permanente nas condições de vida.

Para Menegat, essas tendências correspondem à progressiva perda do caráter social do capital e à ruptura dos laços de sociabilidade que estavam relacionados à produção social das necessidades e à distribuição e consumo das mesmas. Os laços que expressavam o pacto entre as classes que legitimava os Estados nacionais e permitia a construção de um espaço comum representado pela sociedade são esgarçados juntamente com a ampliação da segregação e da violência.

Foucault e Rusche, talvez os mais destacados estudiosos da prisão, previram o fim da parábola histórica do sistema carcerário, com a diminuição da população carcerária (Rusche) e a transição do controle social do cárcere para outras instituições (Foucault). Mas a crescente racionalização do processo produtivo, através de novas tecnologias, teve como consequências a ampliação do desemprego e da marginalização social, originando tensões sociais e aumentando a exigência de disciplina e repressão que possibilitaram a

\footnotetext{
${ }^{7}$ Bourdieu, Pierre (1998). Contrafogos: táticas para enfrentar a invasão neoliberal, Rio de Janeiro: Jorge Zahar.
} 
crítica ao próprio Estado de Direito e o implemento de formas autoritárias de gestão da sociedade.

É nesse contexto que o sociólogo franco-norte-americano Loïc Wacquant afirma que os programas e discursos dos governos, nos estados capitalistas convertidos ao ideário neoliberal, convergem em torno da ideia de "tolerância zero" difundida a partir dos Estados Unidos. Incapazes de impedir a decomposição do trabalho assalariado e de conter a hipermobilização do capital, os governos incrementam o "mais Estado" penal para resolver o problema da insegurança objetiva e subjetiva que é causada pelo "menos Estado" econômico e social, sobretudo o desmonte da rede de segurança social e a desregulamentação do mercado de trabalho.

O avanço global da política de "tolerância zero" é fundado na difusão da "teoria das janelas quebradas". A quebra da janela de uma propriedade, quando não consertada imediatamente, conduziria as pessoas a concluírem que ninguém se importa e não existe autoridade responsável pela manutenção da ordem. Assim, todos passariam a atirar nas janelas até quebrarem todas e iniciar a decadência da rua e da comunidade. Conduzida para o sistema punitivo, a tese fundamenta a ideia de punir as pequenas infrações de modo a conter a violência em sua raiz e evitar a quebra da primeira janela. $\mathrm{O}$ combate à grande criminalidade é iniciado pela repressão aos pequenos delitos. ${ }^{8}$

A amplitude global do fenômeno indica que não se trata de uma mudança meramente quantitativa, mas que está inserida no amplo quadro de transformações da globalização e indica uma "significação muito ampliada da solução institucional como componente da política criminal'9. Há uma crescente necessidade de controlar grupos e segmentos populacionais vistos como uma ameaça à ordem social e que devem ser expulsos forçadamente das relações sociais pela prisão.

Num evidente paradoxo, o mercado é projetado como regulador de todas as relações humanas e o governo é reduzido nas esferas econômica e social, porém, é armado um "Estado forte" no domínio restrito da manutenção da ordem pública, embora essa redução seja a responsável principal pela insegurança objetiva e subjetiva. ${ }^{10} \mathrm{~A}$ violência estrutural dos mercados, exercida na forma de desemprego, precarização e pobreza, tem como contrapartida a lei da conservação da violência, em forma de crimes, delinquência, violência e alcoolismo. As mutações econômicas e políticas condenaram

\footnotetext{
${ }^{8}$ Silveira Filho, Sylvio Lourenço (2007). "Neoliberalismo, mídia e movimento de lei e ordem: rumo ao Estado de polícia". In: Discursos sediciosos: crime, direito e sociedade. ano 11, número 15/16, Rio de Janeiro: Instituto Carioca de Criminologia/ Editora Revan.

${ }^{9}$ Bauman, Zygmunt (1999). Globalização: as conseqüências humanas, Rio de Janeiro: Jorge Zahar. p. 122.

${ }^{10}$ Wacquant, Loïc (2007). "Rumo à militarização da marginalização urbana". In: Discursos sediciosos: crime, direito e sociedade. Ano 11, número 15/16, Rio de Janeiro: Instituto Carioca de Criminologia/ Editora Revan.
} 
parte substancial da população à marginalidade e à consequente "banalização do tratamento penal da miséria social e seus correlatos."11

Para Bourdieu, no mundo das finanças globalizadas, os governos contra-atacam os efeitos violentos da condição cada vez mais precária da grande massa da população com o aumento dos meios, da amplitude e da intensidade da intervenção do aparelho policial e judiciário, que pode ser traduzido na existência segura para poucos e na força da lei para a maioria. Wacquant caracteriza esse movimento como "o surgimento de um novo regime de marginalidade urbana nas sociedades avançadas do Ocidente capitalista e o conseqüente desvio da estratégia governamental na direção da punição da pobreza." As instituições penais tornaram-se o principal instrumento para controlar a desordem resultante do desemprego, trabalho precário e encolhimento estatal. A prisão tem uma função de destaque na manutenção da nova ordem social excludente e autoritária.

A frágil iniciativa política dos Estados nações na era da globalização foi limitada à prisão, que se tornou o principal foco das preocupações dos governos e da elite política na contemporaneidade. Em todo o mundo cresce o número de pessoas nas prisões ou em conflito com a lei, além dos gastos orçamentários dos Estados com a segurança reduzida à questão criminal, sobretudo os efetivos policiais e os serviços penitenciários. $O$ recrudescimento da penalidade contemporânea reafirma a reduzida legitimidade estatal e deixa aos residentes das zonas pobres duas opções: (1) desemprego, empregos miseráveis na nova economia de serviços, trabalhos informais que não violem as leis e com ganhos miseráveis ou (2) tentar a sorte na economia ilegal das drogas e enfrentar a prisão ou a morte.

David Garland assegura que a obsessão por controle penal enraizada no fim do século passado tornou-se uma questão cultural e persiste independente de suas causas e consequências: níveis de criminalidade, efeitos sobre a real segurança, melhoria dos indicadores econômicos, crescimento do emprego etc. Para Garland, são múltiplas e complexas as razões do sucesso da prisão e do controle do crime no mundo contemporâneo: a prisão como instituição civilizada e constitucional de segregação de populações tidas como problemáticas e perigosas; a rapidez e facilidade na implementação que, mesmo fracassando nos demais objetivos, funciona no mínimo como instrumento punitivo; ausência de adversários políticos, custo relativamente baixo e coincidência com a opinião do senso comum sobre as razões da desordem social; preservação da ordem social existente sem mexer com os arranjos econômicos e sociais

11 (2001). As prisões da miséria, Rio Janeiro: Jorge Zahar, p. 128. 
fundamentais; concentração da ação nos grupos subalternos deixando livres o mercado, as empresas e as classe favorecidas; criação de um vigoroso mercado comercial explorado por poderosos interesses privados; e o fato de que os novos métodos não passam a impressão de beneficiar os pobres indesejáveis, não sugerem uma crítica social ou perturbam a liberdade do mercado, ao contrário das formas de regulação próprias do Estado previdência.

Num contexto de insegurança generalizado, flexibilização e precariedade, com a pauperização de amplos contingentes da população, os governos reduziram o sentimento de ameaça à segurança pessoal e a prisão adquiriu a condição de estratégia principal no combate à insegurança. Diante de um amplo quadro de medo e ansiedade, num mundo crescentemente inseguro e incerto, há uma tendência à troca, com amplo apoio popular, de liberdade por segurança. A liberdade tem sido seguidamente sacrificada pela busca contemporânea de segurança, garantia e certeza com o sentimento de medo canalizado nas preocupações com a lei e a ordem.

A diminuição do poder político e o desamparo provocado pela destruição das redes públicas de proteção coletiva geraram uma ansiedade difusa e dispersa que converge para a obsessão por segurança. A incerteza do futuro, a fragilidade da posição social e a insegurança da existência convergem para objetivos próximos e para a forma de preocupação com a segurança pessoal. Uma profunda insegurança econômica e social, pelo esgarçamento do mercado de trabalho e das políticas estatais, é reduzida à dimensão física.

Neste contexto, "a incerteza é vendida como um estilo de vida, e o medo torna-se uma opção estética. Grande parte da produção cultural desse capital desencantado é dedicada a 'pôr medo', paralisar, criar criminalizações e vitimizações, torturadores e torturados, exterminadores e exterminados" ${ }^{\prime 2}$. Malaguti Batista confirma a adoção, no Brasil, do paradigma norte-americano de incremento do Estado Penal como consequência da dissolução do Estado Previdência, com a gestão criminal da pobreza urbana e uma onda punitiva que resulta no maior encarceramento da história da humanidade. ${ }^{13}$

\footnotetext{
${ }^{12}$ Malaguti Batista, Vera (2006). "Filicídio". In: Rizzini, Irene; Corona, Ricardo Fletes; Zamora, Maria Helena; Neumann, Mariana Menezes. (Org.) (2006). Crianças, adolescentes, pobreza, marginalidade e violência na América Latina e Caribe: relações indissociáveis?, Rio de Janeiro: Quatro Irmãos/FAPERJ.

13 "Lei 8.072/90, que veio a proibir a progressão nos regimes instituída pela Lei 6.416/77; a Lei 9.034/95, autorizando o juiz a realizar investigações e julgamentos em procedimentos secretos, colocando-nos de volta à Inquisição e ao sistema inquisitivo da Idade Média; a Lei 7.960/89, autorizando a prisão para investigar, em contraste com o princípio de que primeiro investiga-se e, só depois, comprovada a autoria e existência do crime, é que, por ordem judicial pode-se prender ...; a Lei 9437/97, sancionando, com duras penas, a posse e o porte de arma de fogo (já revogada pela Lei no 10.826/03, o Estatuto do Desarmamento, porém mantendo a mesma substância da anterior); a Lei 9.099/95, definido os crimes de menor potencial ofensivo e, desse modo, trazendo de volta para o sistema penal a grande clientela constituída pela
} 


\section{O DIREITO E A NOVA CONFIGURAÇÃO INSTITUCIONAL: O RDD ENTRE A RECUSA E O CONSENSO}

A Constituição Federal de 1988 foi apoiada nos princípios básicos dos direitos e garantias fundamentais, incorporando, no campo do Direito Penal, Processual Penal e de Execução Penal, a presunção de inocência, a ampla defesa, a individualização das penas, a dignidade do preso etc. A partir da década de 1990, a sociedade brasileira vivenciou um período de adoção do modelo neoliberal, com uma nova visão do direito penal, do processo penal e da execução penal que resultou em profunda transformação da sistemática do modelo punitivo adotado no Brasil. A legislação relacionada à política criminal foi enrijecida, com a flexibilização das garantias constitucionais e a desconstitucionalização fática da legislação infraconstitucional como meio de ampliar a incidência do sistema punitivo.

Desse processo, resultaram ataques às garantias do Direito Penal/Processo Penal/Execução Penal, restrições à defesa, uso do processo penal como instrumento para os objetivos punitivos do Estado e aumento da severidade e duração das penas de prisão e abandono dos ideais de reabilitação. Uma política criminal expansionista e simbólica, despreocupada com a preservação dos direitos e garantias fundamentais, que ataca as garantias pelas quais o liberalismo lutou desde fins do século XVIII.

A crescente complexidade social levou à exacerbação de um direito penal simbólico e ideológico, com a implementação de um sistema penal violento para conservação de uma sociedade crescentemente desigual e injusta. Zaffaroni aponta como as principais consequências jurídicas da nova política criminal a antecipação das barreiras da punição aos atos preparatórios, a desproporção das consequências jurídicas com penas desproporcionais à lesão, a debilitação das garantias processuais e o movimento em direção ao direito penal do autor ${ }^{14}$.

Essa política é adotada apesar de nenhum esforço sério ter comprovado a relação entre política penal e as variações nas taxas de infração, sobretudo quando a violência resulta dos grandes dilemas do mundo contemporâneo. A repressão não tem efeitos

população mais pobre, que dele vinha se alforriando com base no princípio da bagatela; o novo Código de Trânsito e a fantástica gama de proibições, ensejando multas e mais multas, como se o direito penal pudesse atuar como instrumento arrecadatório, dentre outros diplomas legais". Silveira Filho, S. L. (2007). Op. cit., p. 355. Também podem ser citadas: Lei 8.930/94 (aumenta o rol dos crimes hediondos), Lei 9.034/95 (trata do "crime organizado") e muitos outros dispositivos.

${ }^{14}$ Zaffaroni, Raúl (2007). O inimigo no Direito Penal, Rio de Janeiro: Revan: ICC, pp. 14-15. 
sobre a criminalidade, sobretudo quando esta visa criar uma economia informal onde a economia oficial não existe, deixou de existir ou nunca existiu. Inexiste correlação entre nível de crime e encarceramento, e o encarceramento não enfrenta os crimes de sangue, que a mídia alimenta como meio de difusão do medo em relação aos pobres, mas infrações sobretudo ligadas à posse e transporte de drogas, que, pela primeira vez na modernidade capitalista, ultrapassou os detidos por crimes contra a propriedade.

Analisar os ataques às garantias constitucionais liberais no Direito Penal/Processo Penal/Execução Penal não significa desconhecer seus limites e do próprio Estado Democrático de Direito. São débeis os potenciais garantidores do sistema punitivo e é patente a incapacidade da dogmática penal segurar os excessos da violência punitiva que pretendeu ou prometeu minimizar. Diante o caráter estruturalmente seletivo do direito penal, sobretudo nos países de capitalismo periférico, essas garantias não têm a menor eficácia na proteção dos pobres e minorias raciais. À juventude negra e pobre é reservada a eliminação física sem processo através de execuções policiais ou parapoliciais e os benefícios e garantias narradas nos manuais só servem aos iguais, nos raros casos em que são criminalizados. O próprio direito de execução penal é uma utopia, pois aplicado a uma minoria de presos, já que a grande maioria está presa sem sentença, ou seja, por meio das prisões preventivas.

A atuação da própria agência judicial (e consequentemente da dogmática penal) é limitada, pois acontece numa fase avançada da seleção formal e informal, com a anterior ação de diversos filtros seletivos - sobretudo a polícia -, que fazem uma pré-seleção do que será submetido à decisão judicial. A dogmática penal, na prática, é marcada por uma função instrumental latente oposta à declarada e pela função simbólica legitimante.

No presente trabalho, interessa exclusivamente as transformações que ocorreram na execução penal a partir da Lei 10.792/2003 que alterou a Lei 7.210/84 (Lei de Execução Penal), com a análise das mudanças legislativas e dos debates no Congresso Nacional durante a tramitação do projeto de lei. A escolha do Congresso Nacional devese à sua importância como espaço político privilegiado na definição da política criminal, além de ambiente onde ocorrem de forma aberta os embates entre as diversas concepções, agentes (incluindo o Estado) e interesses da sociedade brasileira na formulação da política criminal.

Os discursos e debates no parlamento serão analisados a partir de seus indícios, naquilo que o texto dá a atender sem ter a intenção de dizer, e nos vestígios, detalhes, dados marginais, resíduos e manifestações involuntárias que, em sua repetição, são reveladores. Malaguti Batista afirma a importância de compreender os discursos, 
mensagens e representações em suas funções ideológicas e políticas, pois o importante não é o que a mensagem diz, mas o que esconde. A palavra é um importantíssimo fenômeno ideológico e manifestação da consciência, além de expressão da interação das forças sociais.

A Lei 10.792/03 criou o Regime Disciplinar Diferenciado - RDD e representou significativo endurecimento no sistema de cumprimento das penas, limitando os direitos dos presos definitivos e provisórios, restringindo o contato familiar e interação com outros presos, possibilitando o recolhimento do interno em cela individual com direito a somente duas horas diárias de banho de sol e permitindo que o condenado continue durante 360 dias nesse regime, sem prejuízo de nova inclusão limitada a 1/6 da pena. É a seguinte a redação dada ao Artigo 52 da Lei 7.210/84:

Art. 52. A prática de fato previsto como crime doloso constitui falta grave e, quando ocasione subversão da ordem ou disciplina internas, sujeita o preso provisório, ou condenado, sem prejuízo da sanção penal, ao regime disciplinar diferenciado, com as seguintes características:

I - duração máxima de trezentos e sessenta dias, sem prejuízo de repetição da sanção por nova falta grave de mesma espécie, até o limite de um sexto da pena aplicada;

II - recolhimento em cela individual;

III - visitas semanais de duas pessoas, sem contar as crianças, com duração de duas horas;

IV - o preso terá direito à saída da cela por 2 horas diárias para banho de sol. $\S 1^{0} \mathrm{O}$ regime disciplinar diferenciado também poderá abrigar presos provisórios ou condenados, nacionais ou estrangeiros, que apresentem alto risco para a ordem e a segurança do estabelecimento penal ou da sociedade.

$\S 2^{\circ}$ Estará igualmente sujeito ao regime disciplinar diferenciado o preso provisório ou o condenado sob o qual recaiam fundadas suspeitas de envolvimento ou participação, a qualquer título, em organizações criminosas, quadrilha ou bando. ${ }^{15}$

O modelo do RDD é inspirado no direito italiano, aplicado no combate ao crime organizado na década de 1990. No Brasil, tem origem no estado de São Paulo, instituído através de resolução do secretário de Administração Penitenciária, sob o número 26/2001. O estado de São Paulo valeu-se da regra constitucional do Artigo 24 , $I^{16}$, que concede legitimidade concorrente aos Estados Federados para legislar sobre direito penitenciário. A norma que implementou o RDD em São Paulo é flagrantemente inconstitucional, pois a competência concorrente da União e do Estado é relativa ao Direito Penitenciário, que são as regras próprias de organização prisional, peculiares a cada Estado e relativas ao estabelecimento prisional. O Regime Disciplinar Diferenciado é norma de execução penal e não de mera disciplina prisional, razão pela qual só poderia ser instituída por legislação federal. Os estados não podem legislar sobre matérias

\footnotetext{
${ }^{15}$ Brasil, Diário Oficial da União, seção 1, n²34, 2 de dezembro de 2003, p. 2.

${ }^{16}$ Art. 24. "Compete à União, aos Estados e ao Distrito Federal legislar concorrentemente sobre": I - "direito tributário, financeiro, penitenciário, econômico e urbanístico."
} 
fundamentais de Direito Penal ou de Execução Penal, pois toda regra que crie, modifique, suprima ou reduza aspectos relativos à execução da pena tem natureza penal. Portanto, quando uma norma veda benefícios de execução penal ou cria limitações à liberdade individual tem natureza penal e é de competência privativa da União. Assim, a legislação paulista atingiu a competência privativa da União prevista no Artigo 22, I da Constituição Federal de $1988^{17}$.

Posteriormente, o governo federal, inspirado pelo aparente sucesso do Regime Disciplinar Diferenciado no estado de São Paulo, tentou instalar duas vezes o RDD a nível federal. A primeira, através do Projeto de Lei 5.073/2001, que não obteve sucesso na tramitação no Congresso Nacional e, num segundo momento, via a Medida Provisória 28/2002, mesmo diante a vedação expressa do Artigo 62, § 1, I, "b" da Constituição Federal ${ }^{18}$. A Medida Provisória foi rejeitada pelo Plenário da Câmara dos Deputados em 24 de abril de 2002.

O resultado foi a edição da Lei 10.792/2003, que afronta diversos dispositivos constitucionais, em especial a humanidade na execução da pena. A Lei ataca o princípio constitucional da presunção de não-culpabilidade ${ }^{19}$, ao permitir em seus dispositivos abrigar presos provisórios, ou seja, aqueles que não têm uma condenação definitiva e são presumivelmente não culpados, e ao abrigar presos que "apresentem alto risco para a ordem e a segurança do estabelecimento penal ou da sociedade" ou em casos de "fundadas suspeitas [grifo nosso] de envolvimento ou participação, a qualquer título, em organizações criminosas, quadrilha ou bando". Há ainda contradição com a vedação constitucional a adoção, no Brasil, de penas cruéis (Artigo 5, XLVII, "e" da Constituição Federa ${ }^{20}$ ), a garantia de respeito à integridade física e moral do preso (Artigo $5^{\circ}$, XLIX da Constituição Federal ${ }^{21}$ ) e a individualização da pena (Artigo $5^{\circ}$, XLVI da Constituição Federal $\left.^{22}\right){ }^{23}$

Ao estudar o processo que originou o RDD no Brasil, duas indagações se apresentam: primeiro, o que ocorreu entre 1988 e 2003 para um projeto de lei como o RDD ser aprovado em claro confronto com a Constituição Federal? E a segunda questão:

\footnotetext{
${ }^{17}$ Art. 22. "Compete privativamente à União legislar sobre": I - "direito civil, comercial, penal, processual, eleitoral, agrário, marítimo, aeronáutico, espacial e do trabalho".

${ }^{18}$ Art. 62, § 1ํ. "É vedada a edição de medidas provisórias sobre matéria". I - "relativa a": b) "direito penal, processual penal e processual civil."

${ }^{19}$ Art. 5, LVII da Constituição Federal: "ninguém será considerado culpado até o trânsito em julgado de sentença penal condenatória".

${ }^{20}$ Art. 5, XLVII: "não haverá penas: a) de morte, salvo em caso de guerra declarada, nos termos do art. 84, $X I X ; b)$ de caráter perpétuo; c) de trabalhos forçados; d) de banimento; e) cruéis".

${ }^{21}$ Art. 5, XLIX: "é assegurado aos presos o respeito à integridade física e moral"

${ }^{22}$ Art. 5, XLVI: "a lei regulará a individualização da pena".

${ }^{23}$ Brasil. Diário da Câmara dos Deputados, 15 de agosto de 2001, p. 36745.
} 
o que aconteceu entre 2001 e 2003 para que um projeto que foi contestado em 2001 e rejeitado como medida provisória em 2002 fosse aprovado com o consentimento quase unânime dos parlamentares e partidos políticos no Congresso Nacional?

Proposto em 10 de agosto de 2001, o Projeto de Lei 5.073/2001, em mensagem presidencial com pedido de urgência, conforme possibilidade constitucional presente no Artigo 64, $\$ 1^{\circ}$ da Constituição Federal ${ }^{24}$, teve cancelado o pedido de urgência em 2 de outubro de $2001^{25}$, após solicitação da Comissão de Constituição e Justiça e de Redação da Câmara dos Deputados e a certeza do Poder Executivo de que seria rejeitado:

Solicito a Vossa Excelência promover gestões junto ao Governo para a retirada da urgência constitucional requerida para o Projeto de Lei $n^{\circ} 5.073 / 01$, que "altera dispositivos da Lei $n^{\circ} 7210$, de 11 de julho de 1984, que institui a Lei de Execução Penal, e do Decreto-lei $n^{\circ} 3.689$, de 3 de outubro de 1941 - Código de Processo Penal", pois acompanhando o argumento do eminente Relator, também entendemos que lei de tamanha importância e extensão não deve ficar sujeita a regime de urgência constitucional, prejudicando os debates que necessariamente suscita para sua melhor elaboração, vez que a matéria está ligada a temas dos mais delicados - a privação de liberdade do indivíduo. ${ }^{26}$

Antes, o referido projeto já havia sido rejeitado na Comissão de Segurança Pública e Combate ao Crime Organizado, Violência e Narcotráfico, com o seguinte parecer:

O PL $n^{\circ} 5.073 / 01$, do Poder Executivo, prevê regime disciplinar diferenciado para o condenado que se envolva em outro crime doloso, buscando agravar sua situação dentro do regime penitenciário, inclusive quanto ao direito de visita. Este caminho não parece ser o mais adequado e eficiente na recuperação $e$ ressocialização do condenado, além de revelar-se na contramão do Direito Penal moderno, em que as penas devem levar em conta o caráter humanitário de sua aplicação. $^{27}$

O projeto voltou com bastante força em 18 de março de 2003, após solicitação formulada pelo deputado Luiz Eduardo Greenhalgh ${ }^{28}$ para desapensá-lo de outros projetos de lei que tramitavam conjuntamente, pedido atendido no mesmo dia pelo presidente da Câmara dos Deputados, João Paulo Cunha (PT-SP) ${ }^{29}$. A rapidez do procedimento causou estranheza ao deputado Arnaldo Faria de Sá (PTB-SP), conforme

\footnotetext{
${ }^{24}$ Art. 64. "A discussão e votação dos projetos de lei de iniciativa do Presidente da República, do Supremo Tribunal Federal e dos Tribunais Superiores terão início na Câmara dos Deputados". "§ 1ํ - O Presidente da República poderá solicitar urgência para apreciação de projetos de sua iniciativa".

${ }^{25}$ Brasil. Diário da Câmara dos Deputados, 2 de outubro de 2001, p. 47036.

${ }^{26}$ Ofício do presidente da Comissão de Constituição e Justiça e de Redação, deputado Inaldo Leitão (PMDB-PB), para o presidente da Câmara dos Deputados, Aécio Neves (PSDB-MG). Ofício n¹106/01 de 26 de dezembro de 2001.

${ }^{27}$ Brasil. Diário da Câmara dos Deputados, 28 de março de 2003, pág. 10821. Votaram contra os deputados Morani Torgan (PFL-CE), Ronaldo Caiado (PFL-GO) e Cabo Júlio (PSB-MG).

${ }^{28}$ Partido dos Trabalhadores.

${ }^{29}$ Brasil. Diário da Câmara dos Deputados, 19 de março de 2003, p. 8012.
} 
demonstra sua fala ao presidente da Câmara dos Deputados: "S. Exa. requereu hoje, e já está desapensado o projeto?,30

No mesmo dia, o projeto voltou a tramitar em regime de urgência, a pedido de uma ampla frente partidária e ideológica, mas que parece não ter grandes divergências quando a questão envolve a política punitiva. ${ }^{31}$ No diálogo travado nesse mesmo dia começam a aparecer os vestígios sobre a repentina mudança de posição na Câmara, além dos elementos propulsores da política criminal brasileira, na fala do deputado José Carlos Aleluia (PFL-BA):

Sr. Presidente, quero fazer um apelo ao Deputado Arnaldo Faria de Sá, que se preocupa muito com o aumento da violência, para que não crie obstáculos à aprovação do requerimento de urgência.

A proposta do Deputado Luiz Eduardo Greenhalgh não deixa de ser a resposta possível, no momento, à agressão que se perpetuou conta a Justiça de São Paulo, na pessoa de um juiz, de um homem público que vinha exercendo seu papel com serenidade e firmeza.

Entendo ser a medida muito mais um voto de solidariedade da Câmara dos Deputados à família do juiz assassinado e à família paulista, um grito de protesto do Congresso contra a violência e o crime organizado. Em verdade, não é ação de grande dimensão, mas demonstra que esta Casa, tal como já se manifestou em várias oportunidades, deseja agir de forma enérgica, de acordo com a lei, articulada com os Governos Federal e Estaduais e a Justiça, contra o crime organizado.

É o apelo que faço ao Deputado Arnaldo Faria de Sá. ${ }^{32}$

O deputado Arnaldo Faria de Sá (PTB-SP) afirma:

Sr. Presidente, na verdade, estou preocupado com a situação porque votaremos requerimento para tramitação em regime de urgência de projeto cujo texto não conhecemos. Aprovando a urgência, daremos celeridade à tramitação do projeto. $^{33}$

Mas o deputado foi convencido da urgência na aprovação do projeto e não criou maiores obstáculos. Em 20 de março, o projeto já estava na pauta da Câmara dos Deputados para votação e foi retirado para realização de aperfeiçoamentos e para que o Executivo pudesse apresentar um substitutivo. Em 25 de março, o projeto volta à pauta $e$ é novamente retirado devido à existência de substitutivo apresentado pelo Ministério da Justiça que modificava significativamente o projeto. Afirma o deputado Luiz Eduardo Greenhalgh:

\footnotetext{
${ }^{30}$ Brasil. Diário da Câmara dos Deputados, 19 de março de 2003, p. 8136.

${ }^{31}$ Pedido formulado pelos deputados federais: Luiz Eduardo Greenhalgh, presidente da Comissão de Constituição e Justiça e de Redação; Nelson Pellegrino, líder do PT; José Carlos Aleluia, líder do PFL, Eduardo Campos, líder do PSB, Alceu Collares, vice-líder do PDT; Aldo Rebelo (PCdoB), líder do Governo; Nelson Marquezelli, vice-líder do PTB; e Professor Luizinho, vice-líder do Governo. Diário da Câmara dos Deputados, 19 de março de 2003, p. 8136. O amplo arco partidário já é uma demonstração do apoio suprapartidário e dos mais variados matizes ideológicos do projeto.

${ }_{32}$ Brasil. Diário da Câmara dos Deputados, 19 de março de 2003, p. 8136 e 8137.

${ }^{33}$ Brasil. Diário da Câmara dos Deputados, 19 de março de 2003, p. 8137
} 
Sei da angústia de V. Exa. diante da necessidade de o Parlamento brasileiro dar resposta à altura em relação às execuções penais contra o crime organizado e $o$ narcotráfico. V. Exa., sou testemunha, telefona ao Presidente da Comissão de Constituição e Justiça e de Redação, todos os dias, o dia inteiro, por querer que a matéria seja logo debatida.

Vamos nos comprometer e dizer que o Plenário dará a resposta. O Congresso Nacional estará à altura do momento que vivemos: vamos derrotar o crime organizado e o narcotráfico!

Saiba V. Exa., Sr. Presidente, que sua angústia e preocupação é a angústia e a preocupação de cada um todos nós, Deputados brasileiros. ${ }^{34}$

Em 27 de março de 2003, já tinha sido aprovado por unanimidade o substitutivo apresentado pelo Ministério da Justiça na Comissão de Constituição e Justiça e de Redação:

A Comissão de Constituição e Justiça e de Redação, em reunião ordinária realizada hoje, opinou unanimemente pela constitucionalidade, juridicidade, técnica legislativa e, no mérito, pela aprovação, com substituto, do Projeto de Lei $n^{\circ}$ 5.073-B/2001 e pela constitucionalidade, juridic idade e técnica legislativa da Emenda apresentada em Plenário e, no mérito, pela sua rejeição, nos termos do Parecer do Relator, Deputado Ibrahim Abi-Ackel. ${ }^{35}$

Em $1^{\circ}$ de abril de 2003, o projeto foi aprovado no plenário da Câmara dos Deputados. Os motivos da rápida tramitação ficam evidentes na fala de alguns parlamentares:

Sr. Presidente, Sras. e Srs. Deputados, estamos apreciando o projeto à luz da emoção, em razão do fato de o Dr. Machado Dias, juiz da Vara de Execuções de Presidente Prudente, e de o juiz Dr. Alexandre Martins, de Vitória, no Espírito Santo, terem sido barbaramente assassinados. ${ }^{36}$

Lembro que a matéria veio para esta Casa na forma de projeto de lei, logo após a morte do Prefeito Toninho do PT, de Campinas. Houve uma comoção e veio o projeto, inclusive com urgência constitucional. Quando o Governo sentiu que ele não ia ser aprovado, retirou a urgência.

Em seguida, a matéria foi apresentada na forma de Medida Provisória no 28, de 2002, logo após a morte do prefeito Celso Daniel, de Santo André. Agora, depois de ter sido apensada a outros projetos, foi desapensada e a urgência só foi aprovada por causa da morte do Juiz Antônio José Machado Dias, em Presidente Prudente, agravada pela do Juiz Alexandre Martins, no Espírito Santo. ${ }^{37}$

Embora tenha ocorrido, nas eleições de 2002, renovação de 44,8\% na Câmara dos Deputados, ou seja, dentro da média das últimas cinco eleições (que sempre fica entre $40 \%$ e 50\%), este fato parece o de menor importância na explicação do fenômeno da rápida mudança da posição do parlamento brasileiro sobre o Regime Disciplinar Diferenciado. Chama atenção a constante referência a Fernandinho Beira-Mar e o fato de,

\footnotetext{
${ }^{34}$ Brasil. Diário da Câmara dos Deputados, 26 de março de 2003, p. 9857

${ }^{35}$ Brasil. Diário da Câmara dos Deputados, 28 de março de 2003, p. 10825

${ }^{36}$ Brasil. Diário da Câmara dos Deputados, 2 de abril de 2003, p. 11620, Deputado Arnaldo Faria de Sá (PTB-SP)

${ }^{37}$ Brasil.Diário da Câmara dos Deputados. 2 de abril de 2003, p. 11652. Deputado Arnaldo Faria de Sá.
} 
entre 2002 e 2003, anos anteriores à aprovação do projeto, ter sido o período de constantes transferências de Fernandinho Beira-Mar entre diversos presídios brasileiros: de Brasília para o presídio de Bangu I, no Rio, em 26 de abril de 2002; em 27 de fevereiro de 2003, foi para a Penitenciária Presidente Bernardes, em Presidente Prudente, no interior de São Paulo; e, em 27 de março de 2003, foi levado para a sede da Polícia Federal em Maceió, porém, em 5 de maio retornou a São Paulo.

Todas essas transferências eram acompanhadas de pressão de políticos locais e mobilização da sociedade civil contra a presença de Fernandinho Beira-Mar, supostas negociações de fuzis, granadas e até mísseis, atos preparatórios para assassinato de autoridades, gigantescas escoltas policiais, denúncias de regalias ${ }^{38}$ e, sobretudo, a "venda" do RDD pelos meios de comunicação ${ }^{39}$, até aquele ano implementado exclusivamente em São Paulo, e sua rígida disciplina e isolamento como o único capaz de deter Fernandinho Beira-Mar e a suposta ameaça que representava para os cidadãos brasileiros. Com certeza, isto criava a sensação de maior segurança por alguns dias, até novo episódio.

É de grande importância para compreender a aprovação e o conteúdo da Lei 10.792/03 a construção de subjetividade operada, sobretudo, pela grande mídia, enaltecendo o RDD como a saída mágica para controlar a questão da insegurança no Brasil, resolver os graves e complexos dilemas que afligem a sociedade brasileira e, principalmente, paralisar o principal inimigo da sociedade brasileira naquele período - 0 homem negro, traficante e nascido no morro do Rio de Janeiro que atormentava os sonos dos "bons cidadãos brasileiros".

Nilo Batista define o papel da mídia, sobretudo a televisão, como um "poder excepcional' e instrumento de legitimação simbólica do poder penal e do controle social. ${ }^{40}$ Para o citado autor, a mídia, na contemporaneidade, configura-se como "um conjunto de agências de comunicação social do sistema penal que podem mesmo desempenhar tarefas próprias das agências executivas" ${ }^{\prime 1}$, ressaltando sua enorme parcela de

\footnotetext{
38 Denúncia de regalia de Fernandinho Beira-Mar presente no jornal O Globo: "No Natal de 2005 , 0 traficante gastou $R \$ 500$ para preparar uma ceia dentro da carceragem, que foi dividida com seus seis colegas de cela. No cardápio servido ao bandido por agentes federais, havia pernil de seis quilos, um peru de sete quilos, bolos, arroz à grega, farofa, pudins, salgadinhos, sorvete e refrigerante." http://oglobo.globo.com/rio/mat/2006/12/12/287007471.asp. Acesso em 4. ago. 2009.

39 Não é o objetivo principal do texto debater a questão da mídia, mas uma rápida consulta na versão eletrônica dos principais jornais do país é suficiente para comprovar a tese.

${ }^{40}$ Batista, Nilo (1996). "Fragmentos de um discurso sedicioso". In: Discursos sediciosos: crime, direito e sociedade, Ano 1, número 1. Rio de Janeiro: Instituto Carioca de Criminologia/ Relume Dumará. p. 69.

${ }^{41}$ Zaffaroni, Eugenio Raúl; Batista, Nilo; Alagia, Alejandro; Slokar, Alejandro (2003). Direito Penal Brasileiro: Teoria Geral do Direito Penal, $2^{\circ}$ ed., v. 1. Rio de Janeiro: Ed. Revan.
} 
responsabilidade no que chama de legitimação da hipercriminalização e como instrumento de construção dos conflitos sociais a partir da lógica binária infracional.

Zaffaroni denuncia a função da mídia na difusão do senso comum penal neoliberal, como instrumento "que se move por si mesmo, que ganhou autonomia e se tornou

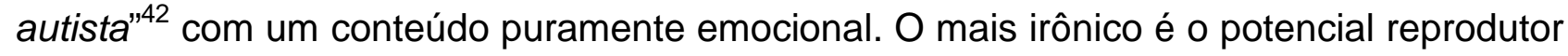
dos efeitos do discurso midiático, ao incitar, num contexto de desemprego, carência e exclusão, a prática de infrações pela denúncia reiterada e incansável do discurso da impunidade e leniência generalizadas e do crime como atividade fácil e impune.

O senso comum punitivo contemporâneo resulta de uma mensagem publicitária onde predominam as imagens. O poder punitivo (a mercadoria que produz audiência) é apresentado como uma mercadoria à venda, sobretudo pelo êxito comercial, num estímulo constante e perspicaz à vingança. "Os serviços de notícias e os formadores de opinião são os encarregados de difundir esse discurso. Os especialistas que aparecem não dispõem de dados empíricos sérios, são palpiteiros livres, que reiteram o discurso único."43 Assim:

\begin{abstract}
[...] vende-se a ilusão de que se obterá mais segurança urbana contra o delito comum sancionando leis que reprimam acima de qualquer medida os raros vulneráveis e marginalizados tomados individualmente (amiúde são débeis mentais) e aumentando a arbitrariedade policial, legitimando direta ou indiretamente todo gênero de violência, inclusive contra quem contesta o discurso publicitário. $^{44}$
\end{abstract}

Nesse contexto, as vítimas e parentes são transformadas nos principais especialistas em segurança pública (técnicos e legisladores) e encabeçam, com amplo apoio midiático, campanhas de lei e ordem em que a vingança é o objetivo principal. As vítimas, com o apoio dos palpiteiros, apresentam a solução para os graves problemas de insegurança que afligem as sociedades modernas no seu período de capitalismo avançado: mais repressão e brutalidade (castração química, pena de morte, prisão perpétua e chacinas).

Os inimigos se sucedem rapidamente, construídos e descartados pelos meios de comunicação, sobretudo a televisão, sitiando as autoridades e impossibilitando o discurso crítico (os que ousam a desafiar o discurso único também viram inimigos). A opinião técnica fica crescentemente encapsulada num círculo limitado e sem o potencial de chegar às massas como o discurso propagado pelos meios de comunicação. Nessa política de construção de inimigos, o próprio Estado pode tornar-se um quando se recusa

\footnotetext{
${ }^{42}$ Zaffaroni, R. (2007). Op. cit., p. 69.

43 Ibidem, p.75

44 Ibidem.
} 
a aplicar as políticas repressivas. Fazendo uma metáfora com a publicidade, Zaffaroni afirma que aquele que nega a qualidade do produto que promove é sempre um inimigo. Mas, como afirma Bauman, se a vida na modernidade líquida está fadada a permanecer estranha, o alívio tem duração instantânea e serão necessárias novas medidas drásticas e decisivas.

Diante da inércia para resolver as graves questões de insegurança, os políticos preferem fingir que estão resolvendo algo, convertendo a política em mero espetáculo para a clientela eleitoral. A população está extremamente atenta à questão criminal e, para os atores políticos, responder a essas preocupações é uma questão de sobrevivência, pois não estar em sintonia com esses sentimentos pode significar um desastre político. À construção de subjetividade em torno das vantagens do RDD juntouse, conforme fica evidenciado nas falas transcritas anteriormente, o assassinato de dois agentes públicos, juízes supostamente mortos pelo crime organizado, formando o cenário ideal para aprovação do projeto de lei.

O liberalismo à brasileira é outro elemento importante para compreender o projeto e suas contradições com as garantias constitucionais e as "conquistas" liberais. Assim como a Constituição de 1824, que mantivera a escravidão, na fórmula de garantir "o direito de propriedade em toda sua plenitude", para não falar abertamente na escravidão numa constituição que se pretendia liberal e manter os privilégios da elite branca, há a visão de que, na Assembléia Nacional Constituinte de 1988, teria havido como um exagero garantista, por ser o momento pós-ditadura militar. Talvez não sem razão, este período ditatorial seja eleito como marco da brutalidade estatal, pois foi a primeira vez em que a violência do aparato policial se dirigiu aos setores brancos e privilegiados. Esquecese que as técnicas utilizadas pelo aparato repressivo da ditadura há muitos séculos dirigese contra a população marginalizada e negra, como garantia das assimetrias na estrutura social brasileira. Agora que a classe média branca não é mais ameaçada pelos generais, mas a juventude negra e pobre dos bairros populares, as "exageradas" garantias não são mais tão necessárias:

O Brasil, hoje, sofre pelo fato de nossa Constituição Federal ter sido promulgada numa época histórica sui generis, em que acabávamos de sair de um regime autoritário. Assim, esse momento histórico, situado em meados dos anos de 1980, elaborou uma legislação e uma Constituição que se preocupou demais com os cidadãos presos por força da perseguição perpetrada pelo regime político de exceção. Assim, deu-lhes vários direitos, atando as mãos do Estado em vários aspectos. Não possuímos mais presos políticos, fruto daquela época. No entanto, nossa legislação não mudou, não seguiu o compasso dos anos democráticos, não previu a explosão da violência. Estados Democráticos e de Direito do mundo inteiro possuem sistemas penitenciários amplamente rígidos, os quais apresentam-se como uma outra forma de se combater o crime. As Supremas 
Cortes desses países não consideram tal rigidez uma afronta aos direitos humanos. A sociedade brasileira clama por mudança e não aceita mais os excessos de hipocrisia e ineficiência de nossa máquina burocrática. ${ }^{45}$

O fim do período da ditadura militar, como afirmam Cerqueira Filho e Gizlene Neder, também reforçou o pânico na classe média alta pela ausência de um controle social autoritário. Com a ajuda da mídia, o "medo branco" manifesta-se como elemento justificante de políticas autoritárias de controle social e de questionamento à ordem democrática.

\section{A PRISÃO NA CONTEMPORANEIDADE: EXECUÇÃO PENAL PÓS-CORRECIONAL}

Bauman afirma que a separação espacial tem sido, ao longo dos séculos, uma importante forma de reação à diferença, sobretudo aquela que não pode ser acomodada ou não se deseja acomodar na rede de relações sociais, sendo o isolamento a principal função da separação espacial. O outro, quando isolado e guardado pelas fronteiras espaciais, sem acesso comunicativo e distante, é colocado na categoria de estranho, sem singularidade individual e estereotipado, o que só reforça a força subjugadora da lei criminal. $\mathrm{O}$ isolamento total permite reduzir o outro à pura encarnação da força punitiva da lei.

As casas de correção inauguradas no século $\mathrm{XVI}$, período de nascimento do capitalismo e da ética do trabalho, visavam, sobretudo, a produção de homens "saudáveis, moderados no comer, acostumados ao trabalho, com vontade de ter um bom emprego, capazes do próprio sustento e tementes a Deus." ${ }^{46}$ O panóptico de Bentham consagrou os esforços para resolver os impasses do trabalho mecânico e monótono da indústria moderna ao adotar o modelo da fábrica de trabalho disciplinado. O controle panóptico desenvolvido por Bentham tinha o objetivo corretivo para o desenvolvimento de hábitos que possibilitariam o retorno e convivência com a sociedade: "interromper a 'decadência moral', combater e extirpar a preguiça, a inépcia e o desrespeito ou indiferença pelas normas sociais" ${ }^{\mathrm{N7}}$, capacitando os internos para uma vida normal.

Quando as máquinas esperavam por mãos dóceis e obedientes para trabalhá-las, os internos desenvolviam um trabalho útil e lucrativo. Os internos trabalhavam, sobretudo, nas atividades que encontravam maior resistência dos trabalhadores livres, as quais dificilmente seriam executadas por livre e espontânea vontade, como a raspagem de pau-

\footnotetext{
${ }^{45}$ Brasil. Diário do Senado Federal, 19 de julho de 2003, p. 19.130. Relatório aprovado na Comissão de Constituição, Justiça e Cidadania e na Subcomissão Permanente de Segurança Pública.

${ }^{46}$ Bauman, Z. (1999). Op. cit., p. 118.

${ }^{47}$ Ibidem, p. 117.
} 
brasil, trabalho pesado e cansativo que dificilmente encontrava executores fora do sistema coercitivo das casas de correção. Diante da falta de disposição dos prováveis operários ao trabalho fabril, a correção tinha o sentido de possibilitar a submissão e quebrar a resistência.

$\mathrm{Na}$ nova realidade do capitalismo contemporâneo, porém, a prisão ganha uma nova dimensão. Para Bauman ${ }^{48}$, o capitalismo contemporâneo exige condições radicalmente antagônicas àquelas que fizeram surgir as casas de correção e o panóptico. Deve-se favorecer hábitos e atitudes contrárias à antiga ética do trabalho, pois, no período da flexibilização, os trabalhadores "devem desaprender a dedicação ao trabalho duramente adquirido e o apego emocional duramente conquistado ao local de trabalho, assim como o envolvimento pessoal no conforto desse ambiente". ${ }^{49}$

Embora bastante discutíveis em seus resultados práticos, pois nenhuma evidência demonstrou a verdade da suposição de que a prisão desempenha as funções a ela atribuídas em teoria, os ideais reabilitadores e preventivos pregados por seus defensores foram abandonados no pensamento dos que trabalham o sistema punitivo na contemporaneidade. A questão da reabilitação, correção ou disciplina é absolutamente irrelevante. A função do sistema carcerário, no surgimento da formação social capitalista, de transformar e produzir o homem, e reproduzir a disciplina como mecanismo geral da sociedade, é superada. $O$ cárcere de segurança máxima é essa expressão máxima.

O RDD é a expressão no sistema punitivo das novas exigências sociais. O RDD objetiva evitar qualquer comunicação dos internos, inclusive com outros presos e funcionários da carceragem, devendo permanecer os detentos a maior parte do tempo, 22 horas, em celas individuais. Nesse regime, nenhum trabalho produtivo deve ser realizado e não se pretende treinar para o trabalho. Mesmo com a disciplina não há grandes preocupaçõe ${ }^{50}$. O importante é os presos ficarem ali, não "como fábrica de disciplina ou do trabalho disciplinado"51, mas como uma fábrica de exclusão, onde devem ser confinados espacialmente o lixo e refugo da globalização. Como afirma o deputado Antônio Carlos Biscaia:

É importante dizer também neste momento que o objetivo da pena privativa de liberdade é a ressocialização do preso. Será que existe perspectiva de

\footnotetext{
${ }^{48}$ Bauman, Z. (1999). Op. cit., p. 119-120.

49 Ibidem, p. 120.

${ }^{50}$ Gizlene Neder trabalha o combate à ociosidade como estratégia de imposição da ideologia do trabalho no Brasil com o fim da escravidão, através de construções de mitologias em torno da honradez e dignificação pelo trabalho. Novos tempos e novas formas de dominação. Neder, Gizlene (1995). Discurso jurídico e ordem burguesa no Brasil, Porto Alegre: Sérgio Antonio Fabris Editor.

${ }^{51}$ Bauman, Z. (1999). Op. cit., p. 120.
} 
ressocialização dos participantes de organizações criminosas? Isso é absolutamente ilusório. Isso nunca acontecerá. ${ }^{52}$

A função do sistema carcerário, na transição do feudalismo para a modernidade capitalista, de transformar e produzir o homem e reproduzir a disciplina como mecanismo geral da sociedade é definitivamente superada. Wacquant concorda com Bauman ao afirmar que o objetivo central da política penal contemporânea é a "defesa social" em desfavor da reinserção, provado pelos estabelecimentos prisionais dominados pela austeridade e segurança. A reinserção foi reduzida a mero discurso publicitário das burocracias, pois a prisão perde seu caráter de reserva de trabalho e passa a ser depósito de seres humanos excedentes sem função econômica ou social.

Nilo Batista segue a mesma direção, ao afirmar que o "novo sistema penal, na sua face dura, não postula do encarceramento as utopias preventivas ressocializadoras, senão a mais fria e asséptica neutralização do condenado." ${ }^{53}$ Gabriel Ignácio Anitua ${ }^{54}$ afirma que o cárcere contemporâneo é mais cárcere do que nunca, inexistindo a utopia reeducativa, pois deve ser um lugar de redução de riscos e de onde ninguém que lá está deva sair.

Nesse contexto, a imobilidade forçada, a prisão em determinado lugar sem poder sair para qualquer outro lugar passa a sensação de abominável, cruel e repulsiva. A proibição de mudar, para além do desejo frustrado, torna a situação especialmente agressiva. "Estar proibido de mover-se é um símbolo poderosíssimo de impotência, de incapacidade e dor. ${ }^{.55}$ Assim, ganha espaço a ideia da prisão e da completa imobilidade como meio eficaz de tirar o poder de pessoas perigosas e de impor a dor pelo mal que praticou.

A prisão, além de imobilidade, expressa expulsão e tem grande efeito simbólico como meio de deixar as ruas seguras. A remoção do perigo para locais distantes, isolados e de onde não possa se comunicar ou escapar é uma promessa de realização desse objetivo. No parlamento brasileiro, a discussão gira principalmente em termos do limite do RDD, sobretudo a limitação a um sexto da pena. Há diversas propostas de emenda ao texto aprovado na Comissão de Constituição e Justiça pela supressão do limite de um sexto, pela ampliação para metade, um terço ou toda pena:

\footnotetext{
${ }^{52}$ Brasil. DCD, 2 de abril de 2003, p. 11623. Deputado Antônio Carlos Biscaia.

${ }^{53}$ Batista, N.; Zaffaroni, R.; Alagia, A.; Slokar, A. (2003). Op. cit., p. 487.

${ }^{54}$ Anitua, Gabriel Ignácio (2008). Histórias dos pensamentos criminológicos, Rio de Janeiro: Revan: Instituto Carioca de Criminologia, p. 819.

${ }^{55}$ Ibidem, p. 130.
} 
Fala-se em 360 dias na solitária, e a emenda que quero seja acolhida pelo Relator é a que suprime o limite em até um sexto da pena aplicada. ${ }^{56}$

Em função do citado artigo, por exemplo, Fernandinho Beira-Mar só poderá, se condenado a doze ou quinze anos, ficar dois ou três anos em regime diferenciado, não mais do que isso. No caso de esse bandido ser transferido para um presídio federal, de isolamento construído na Amazônia, por exemplo, se ele ficar preso lá somente um ou dois anos, quando voltar para o Rio de Janeiro, continuará tudo como era antes, nada se modificará. É essa a preocupação que levo ao Relator. ${ }^{57}$

Talvez tenhamos de manter confinados esses elementos durante toda a extensão da pena, para que o crime organizado possa ser desestruturado. ${ }^{58}$

O prazo máximo de duração do regime disciplinar diferenciado, de 360 dias, ainda limitado a um sexto da pena, como deseja a Câmara dos Deputados, é insuficiente para a contenção de determinados presos que sejam líderes de organizações criminosas. $^{59}$

Quero dizer que o PFL colaborou no que pôde para que a lei fosse hoje aprovada, apesar de termos dificuldades imensas com a questão do limite do confinamento em um sexto da pena. Esse limite gera uma dificuldade muito grande, porque não são dois anos nem três anos que vão desestruturar o crime organizado, que continua exercendo sua liderança de dentro da cadeia. Talvez tenhamos de manter confinados esses elementos durante toda a extensão da pena, para que 0 crime organizado possa ser desestruturado. (Palmas) ${ }^{60}$

O tempo diário de banho de sol, na redação final aprovada limitada a duas horas diárias, também é objeto de grande polêmica, com a proposta de redução para uma hora ou 30 minutos diários ${ }^{61}$, ingênuo desejo de assim tornar as vidas mais seguras. $\mathrm{O}$ preso deve ser absolutamente isolado, como portador de uma doença contagiosa e ameaçadora. Há grande preocupação em evitar o contato físico do advogado com o preso, surgindo inclusive propostas de prévio agendamento da visita do advogado e registros em anais perpétuos para facilitar futuras investigações. Aparecem proposições de que o preso, até cumprir um sexto da pena, não poderia receber qualquer tipo de visita, a exceção do advogado.

As visitas semanais e os contatos com o respectivo advogado serão realizadas em sala com separação termo-acústico entre o visitante e o visitado, sendo a comunicação entre eles realizada por meio de telefone ponto-a-ponto, evitando-se qualquer contato físico. ${ }^{62}$

\footnotetext{
${ }^{56}$ Brasil. DCD, 2 de abril de 2003, p. 11621. Deputado Alberto Fraga (PMDB-DF).

${ }^{57}$ Brasil. DCD, 2 de abril de 2003, p. 11629. Deputado Pompeu de Mattos (PDT-RS)

${ }^{58}$ Brasil. DCD, 2 de abril de 2003, p. 11649. Deputado Moroni Torgan.

${ }^{59}$ Brasil. Diário do Senado Federal. 19 de julho de 2003, p. 19126. Relatório aprovado por unanimidade na Comissão de Constituição, Justiça e Cidadania

${ }^{60}$ Brasil. Diário da Câmara dos Deputados. 2 de abril de 2003. p. 11650. Deputado Moroni Torgan.

${ }^{61}$ Brasil. DCD, 2 de abril de 2003, p. 11635. Emenda n. ${ }^{\circ}$ 13. Apresentadas pelos deputados Cabo Júlio, Renato Casagrande e Luiz Sérgio, os dois últimos vices-líderes do PSB e PT, respectivamente.

62 Brasil. DCD, 2 de abril de 2003, p. 11634. Emenda n. ${ }^{\circ}$. Apresentadas pelos deputados Cabo Júlio, Renato Casagrande e Luiz Sérgio, os dois últimos vices-líderes do PSB e PT, respectivamente.
} 
No Senado Federal, o debate é essencialmente centrado em torno do limite de um sexto da pena. Essa limitação é retirada, de acordo com parecer aprovado na Comissão de Constituição, Justiça e Cidadania e na Subcomissão Permanente de Segurança Pública e depois em plenário ${ }^{63}$ :

O prazo máximo de duração do regime disciplinar diferenciado, de 360 dias, ainda limitado a um sexto da pena, como deseja a Câmara dos Deputados, é insuficiente para a contenção de determinados presos que sejam líderes de organizações criminosas. Se um criminoso perigoso e influente, condenado a uma pena de 6 anos por prática de crime hediondo, cumprir 1 ano de regime disciplinar diferenciado logo no início da execução, não poderá a este voltar se cometer nova falta grave. Poderá fazer o que quiser no presídio, desde matar outro preso até comandar ações criminosas de sua cela, pelos outros dois anos. ${ }^{64}$

Embora tenha encontrado algum nível de resistência, a principal inovação trazida no Senado Federal e mais tarde retirada no retorno à Câmara dos Deputados, assim como as mudanças referentes ao limite de um sexto da pena, foi um novo regime, pois o RDD aprovado na Câmara dos Deputados foi considerado excessivamente benéfico aos "criminosos". Assim, deveria coexistir um duplo regime disciplinar, com fundamento na experiência italiana no início da década de 1990, com a criação do Regime Disciplinar de Segurança Máxima, com duração de 720 dias prorrogável devido "o alcance e a gravidade das atuações de um preso perigoso e influente, líder de uma organização criminosa."65

A proposta de normatização do Regime Disciplinar de Segurança Máxima, no qual para ser inserido bastaria "fundados indícios de envolvimento ou participação, a qualquer título, em organizações criminosas" ${ }^{\prime 66}$, é a seguinte:

Art. 52-A. Estará sujeito ao regime disciplinar de segurança máxima o preso provisório ou condenado sobre o qual recaírem fundados indícios de envolvimento ou participação, a qualquer título, em organizações criminosas.

$\$ 1^{\circ}$ O regime disciplinar de segurança máxima tem por objetivo romper, no interesse público, as ligações do preso com organizações criminosas, e possui as seguintes características:

I - duração máxima de setecentos e vinte dias, sem prejuízo de repetição ou prorrogação, podendo haver conversão para o regime disciplinar diferenciado, ouvidas as partes;

II - recolhimento em cela individual;

III - visitas mensais com o máximo de dois familiares, separados por vidro e comunicação por meio de interfones, com filmagem e gravações encaminhadas ao Ministério Público;

IV - banho de sol de até duas horas diárias;

\footnotetext{
${ }^{63}$ No retorno para a Câmara dos Deputados foi preservado o limite de $1 / 6$.

${ }^{64}$ Brasil. Diário do Senado Federal, 19 de julho de 2003, p. 19.126. Relatório aprovado na Comissão de Constituição, Justiça e Cidadania e na Subcomissão Permanente de Segurança Pública.

${ }^{65}$ Brasil. Diário do Senado Federal, 19 de julho de 2003, p. 19.127. Relatório aprovado na Comissão de Constituição, Justiça e Cidadania e na Subcomissão Permanente de Segurança Pública.

${ }^{66}$ Brasil. Diário do Senado Federal, 19 de julho de 2003, p. 19.131. Relatório aprovado na Comissão de Constituição, Justiça e Cidadania e na Subcomissão Permanente de Segurança Pública.
} 
$V$ - comunicação vedada com outros presos nas saídas para banho de sol e exercícios físicos, assim como entre o preso e o agente penitenciário, devendo os acompanhamentos ser monitorados;

$\mathrm{VI}$ - entrega vedada de alimentos, refrigerantes e bebidas em geral;

VII - proibição de aparelhos telefônicos, de som, televisão, rádio e similares;

VIII - contatos mensais com advogados, salvo autorização judicial, devendo ser informados, mensalmente, à secção da Ordem dos Advogados, os nomes dos advogados dos presos.

$\S 2^{\circ}$ Os presos em regime disciplinar de segurança máxima poderão ficar em unidades federativas distantes dos locais de influência da organização criminosa. $^{67}$

Os artigos finais da Lei 10.792/2003 confirmam o desejo de isolamento total e absoluto dos presos:

Art. $3^{0}$ Os estabelecimentos penitenciários disporão de aparelho detector de metais, aos quais devem se submeter todos que queiram ter acesso ao referido estabelecimento, ainda que exerçam qualquer cargo ou função pública.

Art. $4^{\circ}$ Os estabelecimentos penitenciários, especialmente os destinados ao regime disciplinar diferenciado, disporão, dentre outros equipamentos de segurança, de bloqueadores de telecomunicação para telefones celulares, rádiotransmissores e outros meios, definidos no art. $60, \S 1^{\circ}$, da Lei $n^{\circ} 9.472$, de 16 de julho de 1997.

Art. $5^{\circ}$ Nos termos do disposto no inciso I do art. 24 da Constituição da República, observados os arts. 44 a 60 da Lei $n^{\circ}$ 7.210, de 11 de junho de 1984, os Estados e o Distrito Federal poderão regulamentar o regime disciplinar diferenciado, em especial para:

I - estabelecer o sistema de rodízio entre os agentes penitenciários que entrem em contato direto com os presos provisórios e condenados;

II - assegurar o sigilo sobre a identidade e demais dados pessoais dos agentes penitenciários lotados nos estabelecimentos penais de segurança máxima;

III - restringir o acesso dos presos provisórios e condenados aos meios de comunicação de informação;

IV - disciplinar o cadastramento e agendamento prévio das entrevistas dos presos provisórios ou condenados com seus advogados, regularmente constituídos nos autos da ação penal ou processo de execução criminal, conforme o caso;

$V$ - elaborar programa de atendimento diferenciado aos presos provisórios e condenados, visando a sua reintegração ao regime comum e recompensando-Ihes o bom comportamento durante o período de sanção disciplinar.

A resposta para a nova política criminal não pode ser encontrada na prática ou ideologia dos distintos partidos políticos ${ }^{68}$. A confiança na prisão e no confinamento espacial e incomunicabilidade para resolver a insegurança não é uma questão de disputa política, partidária ou ideológica. Os partidos de esquerda, sem perspectivas de

\footnotetext{
${ }^{67}$ Brasil. Diário do Senado Federal, 19 de julho de 2003, pág. 19.131. Relatório aprovado na Comissão de Constituição, Justiça e Cidadania e na Subcomissão Permanente de Segurança Pública.

${ }^{68}$ Há um grande esforço dos movimentos sociais em inserir suas demandas na esfera penal. Assim fazem o movimento gay, movimento ecológico, movimento feminista, movimento geracional e, tragicamente, o movimento negro, sem dúvida a maior vítima da violência estrutural do sistema penal. $O$ direito penal parece expressar a solução de todas as demandas e conflitos estruturais da sociedade brasileira e surge um número colossal de leis penais para supostamente proteger esses setores vulneráveis. Mais uma nota trágica do capitalismo contemporâneo de barbárie, procura-se abrigo justamente no campo do adversário. Recomendamos a leitura da brilhante análise de Nilo Batista sobre movimento feminista e criminalização: "Só Carolina não viu - violência doméstica e políticas criminais no Brasil."
} 
transformações sociais, também passaram a enxergar na normalidade do presente a única realidade possível. Há um completo acordo sobre essa política criminal ${ }^{69}$, como afirma Bauman: a "única preocupação publicamente exibida por cada uma é convencer o eleitorado de que será mais decidida e impiedosa em prender criminosos do que seus adversários políticos." ${ }^{\prime 70}$ Apelos aos medos gerados pela insegurança estão acima das classes e partidos, como os medos. Para Wacquant, a afirmação do "direito a segurança" pelos políticos de direita e esquerda é simultânea ao silencio sobre o "direito ao emprego" e serve para diminuir a ilegitimidade dos políticos devida à incapacidade de resolver as questões econômicas e sociais. ${ }^{71}$

O projeto é aprovado praticamente por consenso na Câmara dos Deputados e no Senado Federal. A discussão versa, sobretudo, sobre maior ou menor enrijecimento punitivo. No Congresso Nacional, só há dois votos contrários ao projeto, do deputado Arnaldo Faria de Sá e da senadora Heloísa Helena. Parte significativa das manifestações contrárias ao projeto é, em regra, por achá-lo excessivamente complacente com os presos.

\section{CONCLUSÃO}

Concluímos com Cerqueira Filho e Neder, ao afirmarem a importância (talvez imprescindibilidade) de pensar o futuro e o presente como probabilidades, sem os fatalismos que apresentam como inevitáveis as políticas autoritárias de controle social, as quais evidenciam a completa incapacidade de lidar com o Outro. A prisão, o isolamento e a eliminação do Outro não são as únicas possibilidades de solução dos conflitos sociais. Os conflitos, inclusive, podem ser pensados em sua positividade, como possibilidade de construção de novas subjetividades socialmente válidas e que abram caminho para a

\footnotetext{
${ }^{69}$ Independente da sigla partidária e da orientação ideológica há completa sintonia sobre a política criminal: PT, PCdoB, PSB, PMDB, PFL, PSDB etc.

${ }^{70}$ Bauman, Z. (1999). Op. cit., p. 124.

${ }^{71}$ Concordamos inteiramente com as afirmações da Ana Flauzina: "Num plano mais geral, entendemos que o Estado acolhe as pressões do movimento negro a partir do direito penal pelo simples fato de que os efeitos de tais postulações serão necessariamente inócuos. São inócuos porque o direito penal, ao contrário dos demais ramos do direito, é um campo da negatividade e da repressão, não se constituindo como espaço para promover interesses de caráter emancipatório. Além disso, e mais importante, o direito penal se materializa pelo sistema penal. Como engrenagem que toma o racismo como pressuposto de sua atuação, esse sistema é um espaço comprometido, inadequado e incapaz de gerir as demandas a partir de uma perspectiva de igualdade, a exemplo do que ocorre com as demandas femininas. Esse é o campo por excelência de vulnerabilização, e não de resguardo, dos interesses da população negra." O Estado que geralmente é reticente em atender as demandas relacionadas ao trabalho, à saúde, à educação recebe com entusiasmo as demandas de criminalização. Flauzina, Ana Luiza Pinheiro (2008). Corpo negro caído no chão: o sistema penal e o projeto genocida do Estado brasileiro, Rio de Janeiro: Contraponto. p. 92.
} 
convivência nas diferenças. Afinal, a história também é o campo do acaso, da espontaneidade, do desejo, da subjetividade e da transformação.

As contemporâneas políticas autoritárias, da qual o RDD é expressão, são produto de um determinado estilo de política, de uma determinada conjuntura de relações de classe, de uma trajetória histórica própria. Elas são o fruto de escolhas culturais e políticas sobre o modelo de sociedade a ser construída, que podem ser diferentes, repensadas e revertidas em uma disputa construída para além do sistema punitivo. Afinal, há uma intrínseca relação entre sistema penal e estrutura social.

A inflação carcerária e o novo modelo de execução penal fundamentado no isolamento, assim como o seu discurso legitimante, não são uma necessidade natural, mas expressam escolhas políticas, que agravam os problemas que supostamente pretendem resolver, por atingir os estratos mais débeis da população, reforçando a exclusão (de classe e raça) central para entender a sociedade brasileira e que jamais será resolvida pela polícia ou pela prisão.

\section{FONTES}

Brasil. Congresso Nacional. Diário do Senado Federal.

Brasil. Congresso Nacional. Diário Oficial da União.

Brasil. Congresso Nacional. Diário da Câmara dos Deputados.

Brasil. Congresso Nacional. Comissão de Constituição e Justiça e de Redação.

O Globo. http://oglobo.globo.com/rio/mat/2006/12/12/287007471.asp. Acesso em 4 ago. 2009.

\section{REFERÊNCIAS BIBLIOGRÁFICAS}

Andrade, Vera Regina Pereira de (1997). A ilusão da segurança jurídica: do controle da violência à violência do controle penal, Porto Alegre: Livraria do Advogado.

Anitua, Gabriel Ignácio (2008). Histórias dos pensamentos criminológicos, Rio de Janeiro: Revan: Instituto Carioca de Criminologia.

Batista, Nilo (1996). "Fragmentos de um discurso sedicioso". In: Discursos sediciosos: crime, direito e sociedade, Ano 1, número 1. Rio de Janeiro: Instituto Carioca de Criminologia/ Relume Dumará. 
Baratta, Alessandro (1999). Criminologia crítica e crítica do direito penal: introdução à sociologia do direito penal, Rio de Janeiro: Freitas Bastos.

Bauman, Zygmunt (1999). Globalização: as conseqüências humanas, Rio de Janeiro: Jorge Zahar.

Cerqueira Filho, Gisálio; Neder, Gizlene (1997). Emoção e Política, Porto Alegre: Sergio Antonio Fabris Editor.

Chauí, Marilena de Souza (1999). "Ideologia Neoliberal e Universidade". In: Oliveira, Francisco de; Paoli, Maria Célia (Org.) (1999). Os sentidos da democracia - políticas do dissenso e hegemonia global, São Paulo: Editora Vozes/NEDIC/FAPESP.

Bourdieu, Pierre (1998). Contrafogos: táticas para enfrentar a invasão neoliberal, Rio de Janeiro: Jorge Zahar.

Eagleton, Terry (1999). Marx e a liberdade, São Paulo: Editora Unesp.

Flauzina, Ana Luiza Pinheiro (2008). Corpo negro caído no chão: o sistema penal e o projeto genocida do Estado brasileiro, Rio de Janeiro: Contraponto.

Foucault, Michel (1987). Vigiar e punir: nascimento da prisão, Petrópolis: Vozes.

Friedman, Luis Carlos (2007). "O destino dos descartáveis na sociedade contemporânea". In: Melo, Marcelo Pereira de (org.) (2007). Sociologia e Direito: explorando as Interseções, Niterói: PSGDS - Programa de Pós-graduação em Sociologia e Direito - Universidade Federal Fluminense.

Garland, David (2008). A cultura do controle: crime e ordem social na sociedade contemporânea, Rio de Janeiro: Revan.

Malaguti Batista, Vera (2006). "Filicidio". In: Rizzini, Irene; Corona, Ricardo Fletes; Zamora, Maria Helena; Neumann, Mariana Menezes. (Org.) (2006). Crianças, adolescentes, pobreza, marginalidade e violência na América Latina e Caribe: relações indissociáveis?, Rio de Janeiro: Quatro Irmãos/FAPERJ.

Malaguti Batista, Vera (2006). "A questão criminal no Brasil contemporâneo". In: Revista Margem Esquerda - Ensaios marxistas, n. 8. São Paulo: Boitempo.

Menegat, Marildo (2006). O olho da barbárie, São Paulo: Expressão Popular.

Mészáros, István (2004). O poder da ideologia, São Paulo: Boitempo.

Neder, Gizlene (1995). Discurso Jurídico e Ordem Burguesa no Brasil, Porto Alegre: Sérgio Antonio Fabris Editor. 
Rusche, Georg; Kirchheimer, Otto (2004). Punição e estrutura social, Rio de Janeiro: Revan/ICC.

Silveira Filho, Sylvio Lourenço (2007). "Neoliberalismo, mídia e movimento de lei e ordem: rumo ao Estado de polícia". In: Discursos sediciosos: crime, direito e sociedade, Ano 11, número 15/16. Rio de Janeiro: Instituto Carioca de Criminologia/ Editora Revan.

Wacquant, Loïc (2008). As duas faces do gueto, São Paulo: Boitempo Editorial.

Wacquant, Loïc (2007). "Rumo à militarização da marginalização urbana". In: Discursos sediciosos: crime, direito e sociedade, Ano 11, número 15/16. Rio de Janeiro: Instituto Carioca de Criminologia/ Editora Revan.

(2001). As prisões da miséria, Rio Janeiro: Jorge Zahar.

Zaffaroni, E. Raúl (2007). O inimigo no Direito Penal, Rio de Janeiro: Revan: ICC.

Zaffaroni, Eugenio Raúl; Batista, Nilo; Alagia, Alejandro; Slokar, Alejandro (2003). Direito Penal Brasileiro: Teoria Geral do Direito Penal, 2o ed., v. 1. Rio de Janeiro: Ed. Revan.

Recebido para publicação em julho de 2010. 